\title{
Faculty Mentoring Undergraduates: The Nature, Development, and Benefits of Mentoring Relationships
}

\begin{abstract}
Educational research shows that close student-faculty interaction is a key factor in college student learning and success. Most literature on undergraduate mentoring, however, focuses on planned programs of mentoring for targeted groups of students by non-faculty professionals or student peers. Based on the research literature and student and faculty testimony from a residential liberal arts college, this article shows that unplanned "natural" mentoring can be crucial to student learning and development and illustrates some best practices. It advances understanding of faculty mentoring by differentiating it from teaching, characterizing several functional types of mentoring, and identifying the phases through which a mentoring relationship develops. Arguing that benefits to students, faculty, and institutions outweigh the risks and costs of mentoring, it is written for faculty who want to be better mentors and provides evidence that administrators should value and reward mentoring.
\end{abstract}

\section{KEYWORDS}

Mentoring, faculty-student interaction, undergraduate teaching, faculty development, student development

Educational research consistently points to the importance of student-faculty interaction in fostering positive learning outcomes. In devising their now-canonical "Seven Principles for Good Practice in Undergraduate Education," Chickering and Gamson (1987) put "encourages contacts between students and faculty" first on the list. ${ }^{1}$ Pascarella and his colleagues (2005) found that frequent student-faculty contact is an independent variable that positively affects student outcomes. ${ }^{2}$ Similarly, the ongoing Wabash Study of Liberal Arts Education (2013) identifies high-quality interaction with faculty, both in and outside the classroom, as one important determinant of student learning. ${ }^{3}$ Based on a survey of 30,000 college graduates, the recent Gallup-Purdue Index report shows long-term benefits: those who are most engaged in their current work and who feel the greatest sense of general well-being had faculty in college who made them "excited about learning," cared about them "as a person," or served as "a mentor who encouraged [them] to pursue [their] goals and dreams" (Ray \& Kafka, 2014).

Such studies call to mind the famous image of "the ideal college" promulgated in 1871 by James A. Garfield (Williams College graduate, later U.S. President), as "Mark Hopkins [his favorite teacher] on one end of a log and a student on the other" (Garfield, 1871). Despite tremendous changes since then, this image of professor and student engaged in close intellectual conversation-a mentor guiding the development of a novice-persists as an ideal of undergraduate teaching and learning. Indeed, cozy pictures in college admissions materials of faculty talking with individual students seem to indicate that mentoring is alive and well on campus, as if it happens automatically. 
Nevertheless, the forces working against such one-on-one student-faculty interaction are intensifying. The erosion of public funding and private philanthropy, coupled with increasing costs and public outcry against rising tuition, have pressured institutions to become more efficient by increasing class sizes, hiring more contingent faculty, and substituting on-line courses for face-to-face classes. Apprehension about student debt and bleak job prospects make students and families focus on the cost and material benefits of college. At the same time, faculty feel pressure to devote themselves to research, the source of both individual prestige within their disciplines and institutional standing in the race for higher rankings; research is paramount in getting a job or promotion.

Apart from these exogenous barriers, an important obstacle to mentoring - the one I address here-is our vague understanding of just what it is. The term derives, of course, from Mentor, the character in Homer's Odyssey (actually the goddess of wisdom Athena in disguise), who gives Telemachus the advice and encouragement he needs on his quest to find his father. Hence, the American Heritage Dictionary defines "mentor" as "a wise and trusted counselor or teacher." To mentor, then, is to provide wise advice and instruction.

But mentoring is not the same as teaching. In fact, in popular usage, mentoring is almost never based on formal teaching; it occurs in after-school programs, the neighborhood, or workplace. Based on post-World War II models of human development, such as those of Erikson (1950), Perry (1970), or Levinson (1978), contemporary ideas of mentoring focus on helping someone move successfully from one life or career stage to another, toward productive maturity. Formal mentoring programs have burgeoned in corporate, professional, and educational settings (e.g., for women in business, minorities in STEM graduate programs, first-year students from under-represented groups at mainstream universities). In turn, there is now a rich literature on mentoring in the corporate world (Levinson, 1978; Kanter, 1977; Kram, 1983), in higher education for both faculty and staff (Dallimore, 2001; Rao, 1998; Schmidt \& Wolfe, 1980), in graduate education (Horowitz \& Christopher, 2013; Lipschutz, 1993), in teacher training (Krockover, 1991; Wildman, Magliaro, \& Niles, 1992), and for undergraduates from under-represented groups (Apprey, 2014; Dodson, Montgomery \& Brown, 2009; Leon, 1993; Terrell \& Haskell, 1994). In most of these cases, mentors are more experienced professionals orienting newcomers to the work, standards, and culture of the organization or profession; in some they are more experienced peers.

There is not a lot of literature on undergraduate mentorship by faculty, however, and much of what has been written conflates mentoring with teaching and misses mentorship's distinctive elements that range beyond what we normally expect from classroom teaching, both in form and content. Even the contributors to the volume Beyond Teaching to Mentoring (Reinarz \& White, 2001) conceptualize mentoring as especially effective teaching. For example, the lead essay "Mentoring as Metaphor" regards mentoring merely as metaphor, useful to encourage professors to reframe teaching not as performance or imparting knowledge but enabling student learning (Enerson, 2001, p. 11). Through much of this volume, contributors use the idea of mentoring to promote the most effective kinds of teaching - giving formative feedback on student work, tailoring curriculum to students' prior knowledge, promoting active or collaborative learning, providing opportunities for student-faculty research - good practices all. But counsel and encouragement beyond the framework of the course or research lab — mentoring — they relegate mostly to adjunct professionals or graduate student assistants. ${ }^{4}$

Undergraduate mentoring can grow out of teaching or research supervision, but goes beyond these functions, and students understand this. One young graduate offered this testimony about a faculty member in an evaluation submitted for that faculty member's tenure review: 
I regard [Professor A] as my 'academic mother,' and often I consider her solely responsible for the opportunities I have had at and after [college]. Because of the research experiences she gave me and because she shared her enthusiasm for [her subject] with me, I am currently in graduate school [in the same field] in hopes of becoming a professor like her.... She was not only an excellent teacher and research supervisor but also a mentor and friend. ${ }^{5}$

Good teachers and research supervisors help advance one's knowledge and skills, but mentors are credited with life-changing inspiration and support. At the same time, mentors gain unique satisfaction from mentorship. Professor A herself spoke eloquently of her passion to inspire students to become independent learners; such mentoring "felt natural, delightful, and non-stressful."

\section{METHOD}

The alum's quotation above is from one of more than 9200 qualitative student evaluation questionnaires I read during my thirteen years as Chief Academic Officer of a selective residential liberal arts college in the U.S. with traditional age students, as part of 182 faculty reviews (third-year and tenure reviews, as well as special reviews for non-tenure-track faculty) that I supervised. I was continually struck that faculty who consistently got the highest ratings from students and young alumni were often praised not just for their classroom work or their advising, but for being inspiring "mentors" (a word not included on the evaluation form but one that students spontaneously chose themselves), a role students clearly differentiated from teaching and advising. Some faculty described mentoring in their professional statements (whether they named it or not), and I discussed it with them in the conversation mandated for each review; the Faculty Tenure and Promotion Committee that I chaired also noticed and discussed this phenomenon. For this article, I chose the review files of twelve faculty members whose praise as mentors was most robust and salient (all received tenure) and analyzed both the student evaluations (774 in total) and faculty professional statements for themes and patterns; quotations in this article are taken from those files with Institutional Review Board approval (if student comments are made anonymous, which I did by redacting identifying details, and if faculty gave permission, which I obtained in writing). ${ }^{6}$ I then reviewed the literature on mentoring (which is vast), particularly that on undergraduate mentoring (not so vast), to test and organize my findings. My goal is to advance understanding of best practices in mentoring traditional-age undergraduate students from both student and faculty perspectives; in doing so, I identify several types of mentoring, phases of most mentoring relationships, risks, and rewards of undergraduate mentoring by faculty.

\section{WHAT IS MENTORING IN AN UNDERGRADUATE SETTING?}

Jacobi (1991) reviewed the literature on undergraduate mentoring and found no consensus definition, so she quoted fifteen different definitions, including one from a researcher writing a decade earlier: "At a superficial level everyone 'knows' what mentoring is. But closer examination indicates [such wide variation...] that the concept is devalued, because everyone is using it loosely, without precision, and it may become a short-term fad" (Wrightsman, 1981, pp. 3-4, as cited in Jacobi, 1991, p. 508). Hardly a fad, mentoring has proliferated on campuses in myriad programs designed for target populations (e.g., first-generation students, first-year students from under-represented groups, women in engineering, etc.), and the research literature - as reviewed in updates to Jacobi by Crisp and Cruz (2009) and Gershenfeld (2014) — has consequently focused mostly on such formal mentoring programs. Depending on the program, its activities and goals differ, which contributes to definitional confusion, and Crisp and Cruz report fifty different definitions in the work they reviewed. 
Another source of confusion is the co-existence of two structurally distinct forms of mentoring, "formal" or "informal," "planned" or "natural" mentoring. ${ }^{7}$ All mentoring programs which recruit mentors and assign them to mentees (whether first-generation students, novices in the corporation, new faculty, young women studying engineering, or minority administrators) are examples of planned mentoring. In contrast, "natural" mentoring is less intentional on the institution's part, more organic or spontaneous, and certainly not assigned. While planned mentoring can be valuable - assigned mentoring programs for first-year faculty and for incoming minority, first-generation, and international students have had definite benefits at my institution and many other colleges - and is much easier to study, ${ }^{8}$ my focus here is on natural mentoring of students by faculty. Carger (1996) argues this is the only effective kind of mentoring: "you cannot assign mentors any more than you can mandate friends" (p. 29). This is what the student quoted above implied.

It is also the case that this student did not define "mentor" but used a metaphor: Professor A was an "academic mother." Such metaphors often arise in the literature to help define mentoring: it is coaching or apprenticeship, the mentor is patron or sponsor or guru. Students and faculty in my sample also use metaphors like "building bridges" or "belaying a student down the rock face," guiding a journey or taking the mentee "under one's wing." All these analogies point to something larger than teaching: a faculty member advising, encouraging, supporting a student in a one-to-one relationship that promotes growth and development, academic and personal. ${ }^{9}$ Because traditional age undergraduates experience tremendous change in college (they are in the overlapping stages of late adolescence and emerging adulthood, according to Levinson's (1978) model), the kind of mentoring they need changes over their college years. Because mentoring takes place within a relationship, it is dynamic and changing. Mentors may serve as advisors, role models, friendly critics, supporters; they challenge, encourage, and inspire. No two mentoring relationships are exactly alike, but some useful generalizations are possible.

\section{STAGE-TYPES OF MENTORING FOR UNDERGRADUATES}

Functionally, I have identified three basic types of undergraduate mentoring, based on the students' stages of progress through their college experience; the stage of the students' college career determines the timing of mentorship as well as the content of "what's on the table" in mentoring interactions. The first stage-type is Mentoring In: helping newcomers get oriented and "learn the ropes." Such mentoring can focus on college life in general or on a particular subject and activity; it includes orientation to college standards and skills, initiation into the particular campus ethos, and help in learning the methods and language of a discipline. Most campus mentoring programs for underrepresented students are designed to accomplish such tasks, but faculty outside structured programs also undertake this kind of mentoring. For example, at my institution, where there is a foreign language requirement, one language faculty member wants to enable her students to go abroad and communicate fluently, so she structures all her courses, even the beginning one, with this goal in mind by including opportunities outside the classroom to get to know students and push them to consider off-campus options suitable to their interests. She describes her role as helping students "step into the unknown" and walking with them "until they can stand on their own, enriched with fresh knowledge and renewed confidence," and eventually march "towards new horizons." Adopting a common metaphor for mentoring, she wants to guide students on their journey — to lead the tour, if you will—until they can travel on their own.

A second stage-type of mentoring might be called Mentoring Through: helping students acquire and apply more advanced skills, gain confidence, and begin to achieve autonomy in their work. This may evolve from a student doing research in a faculty member's lab or undertaking "independent 
study" under a faculty member's direction, but it also happens through supplemental interactions outside of class. Typically a student who praises a faculty member for being "a great mentor and professor ...value $[\mathrm{s}]$...the time he has taken to talk to me in other settings" outside of class. One student extolled a faculty member for going "out of his way to give me personal help.... I talked to him about my fear of speaking up in my classes and he was really helpful.... He really made a difference for me."

Occasions for Mentoring Through can arise any time, and may even be recognizable only in retrospect. An alum, fifteen years into a business career, commented to me in casual conversation that he wasn't really mentored in college. But a week later, he wrote me a note correcting his initial memory. He recalled in particular "one professor who gave me very helpful direct and personal guidance during a time when I was struggling with his class and had sought him out during office hours.... $[\mathrm{H}] \mathrm{e}$ took a personal interest in providing real coaching and guidance-very different from simply teaching his course material."

Coaching (or teamwork) is a metaphor frequently used by professors as well as students to capture the value of personal interactions outside the formal classroom setting. For example, one faculty member described the first off-campus study program he led as an "experience [that] presents a new and more powerful way of coaching and teaching students in the social sciences than anything I have experienced in the classroom." It was a particularly good place for him to "listen well to students, to provide a sounding board for their ideas, to challenge them to consider alternatives and to encourage them." A similar sense of close relationship is conveyed by a student whose favorite professor "treated us with a respect and a candor that made us feel more like his peers rather than his students, as if we are all members of the same team (and he is its captain)." Whether using the language of coaching or not, these are examples of Mentoring Through a challenging course, a new learning experience, or a rough time for the student.

The third stage-type of undergraduate mentoring might be called Mentoring Onward, that is, looking ahead to life after college, considering alternatives for jobs, careers, graduate school, etc. Many senior thesis advisors, as well as those formally charged with pre-medical or pre-law advising, give advice about graduate school or career options. But not all rise to the level of mentoring in this role. Students single out those faculty with a particular "willingness to help students with decisions about life after [college]. [Professor B] encouraged me to apply for graduate fellowships and to apply to top graduate schools. Without her support I would not have been aware of the many opportunities available to me." This is mentoring because the professor not only gave advice for the future, but also supported the student's process of self-assessment of strengths and goals and helped instill confidence. Another student said of the same professor, "she taught me to believe in myself and encouraged me to continue on to graduate school. She is largely responsible for giving me the courage and self-confidence to pursue a career in science." Similarly, from another student about a different faculty member, "[Professor C]'s ability to guide with honesty and tact was one of her strengths as a research advisor. Because she respects her students and treats them as her colleagues in research, she nurtures independent thinking.... [As a] mentor ...she listened to my dilemmas about the future and provided advice."

All mentoring, it should be noted, is forward-looking, helping students grow and prepare for their next tasks and challenges. But Mentoring Onward is most explicitly focused on a student's "dilemmas about the future" — on career and life choices — that are a common source of stress and anxiety for undergraduates. Young adults often feel "stuck," unable to resolve questions, clarify values, or reach decisions about their first steps into the "real world," outside the protective "bubble" of college. They may feel paralyzed, unable to assimilate the rich sources of information available through career centers, alumni networks, or on-line resources. They may have trouble sorting through parental 
expectations, internal pressures they may only vaguely articulate, or ideals they imagine they should embrace. An experienced mentor is alert to the signs of "dilemma stress" and is skilled at asking the delicate questions that can help students untangle their thinking, set priorities, and achieve a tentative sense of comfort with their decisions. Pragmatically, such mentorship often leads to sponsorship for fellowships, referrals to relevant people inside and outside the academy, and writing references for graduate schools or jobs, but providing confidence-building support and posing the questions that will help students reflect on their own strengths and weaknesses, penchants and aspirations are at the heart of mentoring. As Cohen (1991) emphasizes, a mentor's primary role is to inspire reflection in the student.

\section{PHASES OF ESTABLISHING A MENTORING RELATIONSHIP}

Every mentoring relationship, no matter at what stage of a student's progress through college, goes through two or three key phases of development. The most basic step is connection. An initial sense of connection can occur "from a distance," through what has been called "role modeling." Indeed, some of the early literature on mentoring seemed to assume this was the essence of undergraduate mentoring. For example, Erkut and Mokros (1984) describe a survey of students at six liberal arts colleges that focused solely on qualities in faculty whom students admired; the researchers asked nothing about actual relationships between students and their teachers. Admiration can inspire students to take another course from a faculty member or to major in the field. For example, one student who intended to major in a different field, reported: "I only took my first class [with this professor] out of casual interest. After my class with him, however, I felt that so much had been explained to me so well, and the information made such wonderful sense to me that I simply had to pursue this field!" Another student generalized about the power of a strong sense of connection between teacher and student: "A remarkable professor interacts and teaches with an intelligent enthusiasm that is contagious. A part of you says, 'I want to be just like her or him!'”

Most contemporary students want closer interaction with faculty. They praise a professor who "gets to know everyone in his classes. I was very impressed by how much personal interest he took in his students. He always knew how everyone was doing in the class. He really wanted everyone to do well and went far out of his way to help students that came to him. He cared about his students." Such appreciation for faculty who "take the time to get to know their students, not just to teach them" is a recurrent theme in the most positive student evaluations.

Connection is encouraged when faculty are available and accessible to talk outside of class. This means holding enough office hours so that conversations can be more than cursory, but it also requires approachability, making students feel invited and welcome when they do come. Students appreciated one professor for holding occasional office hours in a local coffee house on Saturday mornings, for, as one said, "To meet outside [the academic building] lent those meetings more of an aspect of collaboration and discussion, instead of something official or dictated." Students interpret such faculty efforts as evidence that faculty care about them as people, not just as students. On faculty evaluation forms, students often list "accessibility" or "availability" as a criterion for faculty effectiveness. Sometimes the Tenure and Promotion Committee has worried that this may signify that the professor encourages dependence or "coddles" students. But understood in context, such student emphasis on faculty accessibility is a corollary to students' academic engagement and is clearly a sign they are hungry to interact with faculty, eager to know them and be known by them, to establish a connection-a relationship that can open the way to mentoring. 
Students are empowered when faculty get to know them well enough to see their potential. One was profoundly influenced by a professor who "focuses on the other person with full attention and, in my experience, with a knack for spotting the giftedness of the other person. His belief in my abilities startled me, and my self-confidence grew significantly through knowing him as a professor." Another praised a teacher who "makes a good mentor, displaying a real interest in the growth and education of her students.... She encourages frank discussion and honest [communication.... Her] integrity, intellectual authority, and passion for the subject matter were...contagious."

Building on connection, the next stage in a mentoring relationship is often collaboration. Individual projects such as student-faculty lab research, independent study, a senior thesis, or research assistance on a faculty project are salient examples. One student recalled floundering in her chosen science field until the summer after sophomore year when she worked closely with a faculty member:

It was through my work in her lab that I found myself and the success that had eluded me since my arrival at college. I made many mistakes but [Professor D] was always positive and confident in my abilities. I regained my self-confidence and did some good work for her.

The student subsequently presented at several conferences and received Honors in Independent Study. She concluded her tribute by saying, "I am indebted to [Professor D] for the experiences I gained working in her lab. She is my mentor and my friend, and I have the utmost respect for her."

Collaboration can begin within a classroom setting. "[Professor E] was constantly learning with us," wrote one student. "She would assign problems that she did not know the answer to. The feeling of working in conjunction with your professor was amazing." Another remarked about a different professor, "Never have I met a teacher with such devotion to her subject and her students, or who afforded her students so much respect as co-participants in the learning process." Such focus on student learning in the classroom, now understood as a hallmark of effective teaching, opens the way to mentoring.

Sometimes full-fledged mentorship can develop without an actual collaborative project, but with or without collaboration, the connection must be strong before the culminating phase of mentoring can develop: a sense of mutual commitment. One student emphasized that

faculty [should be] interested in and committed to the students. Faculty members should be available to meet with students, be interested in the academic work and the real lives of the students, make an attempt to know each student, and be willing to challenge the students and help them grow.

In describing an ideal teacher, this student is also describing the elements essential to a full-fledged mentoring relationship. Students often use the word "friend" or "mentor" to describe such a "thirdphase" relationship, as in this accolade: "[Professor F] made himself available to students at many levels: professional, personal, as a mentor, teacher, and friend. He consistently held students to a high standard, but his comments were always fair and constructive."

Full-blown mentoring (especially Mentoring Onward) can take a lot of time-encouraging reflection, writing recommendation letters, giving advice and support-and therefore requires a real faculty commitment to the student. But the commitment is mutual; the student commits his or her future to the faculty member's wisdom, at least in part, trusting that the questions asked will be 
enlightening and the reflection invited worthwhile, the recommendation convincing, the advice relevant. As Ream, Lewis, Echeverría, and Page (2014) emphasize, trust is required on both sides.

These phases - connection, collaboration, and commitment-occur in each stage-type of mentoring, whether Mentoring In, Mentoring Through, or Mentoring Onward. But as students mature and move through college, they will likely have more opportunities for collaboration with faculty, and as they look ahead to their lives after college where the stakes seem even higher, the importance of commitment on both sides increases. So collaboration may be more prominent in Mentoring Through, and commitment more salient in Mentoring Onward, but there is no exact correlation between what I've called the Stage-Types of Mentoring (the focus) and the phases of mentorship's development (the character of the relationship).

Sometimes, mentoring will move into a fourth phase, a continuing relationship. Many of the deepest, most important mentoring relationships continue after graduation; eventually, mentoring can grow into real collegiality (when a student becomes a colleague in the academic discipline) or friendship (no matter what the career path). Sometimes younger faculty are surprised by how rewarding it feels when alumni keep in touch. One noted that "I have become very attached to my students.... Alumni contact me regularly to chat and continue conversations that were left dangling at the end of spring term their senior year. These moments take their place among the most rewarding and enjoyable events of the year." 10

\section{MENTORING DISTINGUISHED FROM TEACHING}

How is mentoring distinguished from good teaching? As noted, students describe a good mentor as going "out of his way" for the student or "above and beyond" normal course-based duties. Mentoring often takes place outside the classroom or office, in informal settings - in a departmental lounge, college quadrangle, or coffee shop, in the faculty member's home, after a performance or lecture or competition, on a field trip. Such settings encourage conversation beyond course-related topics.

Boyer (1996) differentiates an effective mentor from a good teacher: a "mentor not only has a love of learning, but above all a love of students" (p. xii). In other words, a mentoring relationship, unlike teaching, is personal. Mentors care about individual students. As one student testified, "[Professor G] is genuinely concerned not only about the academic well-being of her students but about their overall well-being. She always took the time to find out how I was doing, even in my last two years when I didn't have her as a teacher."

Effective mentorship inspires personal reflection by the student. As Cohen (2001) emphasizes, "the mentor's task is not to serve as a role model, but to engage students in a process of careful reflection"; mentoring is "an active relationship between student and teacher in which the mentor provides the opportunity for guided reflection" (p. 54). This is what one mentee celebrated in saying that her mentor "taught me to listen to my inner compass, to define for myself what it means to do great things in the world." Effective mentoring requires asking astute questions and providing encouragement, but it also sometimes includes challenging a student; as one alum said of his faculty mentor, "I feel honored that he respected my mind enough to be hard on me."

When students couple the terms "mentor" and "friend" in characterizing an influential faculty member, they point to the individual, personal nature of mentorship. Yet mentoring is not the same as friendship, and the content of mentoring conversations need not include personal or private information. One description of an "amazing" mentoring relationship clarified that 
it's personal but it has appropriate boundaries. [Professor H] teaches me-it has a directional flow - but he reveals himself too, he lets me into his thinking process. He always keeps the right balance and it's mostly about the mentee, about helping me understand my strengths and goals. It makes me want to give back at some point, to pass it on to others.

This tribute points to the holistic nature of a true mentoring relationship. Both student and faculty member are engaged as whole people. Part of the "work" undergraduate students must do is to "grow up" as individuals as well as to develop intellectually, to learn to make good personal choices as well as career-directed decisions. Their task is to become autonomous, integral adults, and they need examples, guides, and sounding boards as they establish their own values and goals. Students need the personal, holistic recognition and respect as whole people that they get from faculty who have "a genuine interest in ...students' lives both in and out of the classroom" (my emphasis). Students learn better when they are engaged as whole people.

Faculty, too, are more effective and satisfied if they feel whole in their teaching and advising. As one explained:

When I began teaching, I assumed that I must strive for objectivity. Over time I have learned that academic pursuits can never be divorced from personal experience. Inevitably, our emotional and psychological experiences help to shape not only our intellectual interests, but also how we learn and what we do with what we learn.

Now, he continued, "I try to build a bridge between the personal and the academic," and he is more effective and satisfied in his work. Students are moved when professors offer what Chickering and Reisser (1993) term "appropriate self-disclosure" (p. 329). For example, one student praised a professor for teaching as a whole person: "He shares his life with his students, from talking about his kids to explaining his favorite research problem from graduate school." Another attested that a professor's "sharing of herself and her work was extremely effective in inspiring and motivating me." And a third identified a faculty member who had shared his own experience as "an important mentor to me in thinking about the way thought and action can overlap." Part of effective mentorship is offering what Kartje (1996) calls a "gift of self" (p. 122).

New faculty sometimes have to learn that this is okay, or better than okay. Often the atmosphere in the large research university where faculty members were graduate students is formal and fragmented, and teaching assistants are encouraged to spend as little time as possible with students. (I remember vividly, when I was a young faculty member at such an institution, being explicitly warned not to become "a student-lover," that is, not to spend much time and effort with students. Recently, a graduate student at the same institution was advised in the teaching assistants orientation to hold only one office hour per week, in order to limit attention spent on undergraduates.) New faculty coming out of such a graduate school environment may need some "retraining" if they are to become effective mentors.

Evidence in the thousands of student evaluations I've read indicates that many students are seeking models of integrity and wholeness in their faculty. One was explicit in saying that a professor who loves his subject matter but "doesn't make it the centerpiece of his life" provides a "good role model" for balance in life. Another wrote, "Part of being a great teacher is being a great person, and [Professor I] is this. Probably two years after having him as a teacher, I went to him with a personal concern. He was gracious in the utmost, honest, and-I don't know how to describe it - solid in his humanity. He was a source of inspiration." Another student wrote in a thank you note to a faculty 
member after graduation, "It meant a lot to me to have a professor who explicitly linked education with justice in the world; a professor who had moral as well as intellectual expectations of his students." In these cases, students learned things about their own lives from faculty who shared something of their values and wholeness with them. Boyer (1996) sums up the benefits of holistic mentoring by saying, "A mentor respects students' urges to broaden their own vision of who they are and what they might become, and a mentor lives a life that embodies the beliefs that he or she espouses" (p.xii).

\section{RISKS OF MENTORING}

As with all human relationships, there are risks involved in mentoring. It may take too much time or encourage dependence on the part of students. Faculty need to set limits to avoid these dangers, for their own and their students' sake. Given the power differential between faculty and students, and the developmental vulnerability of the traditional college years, mentors must take particular care and responsibility as a relationship develops. One risk is that a mentor might become over-involved in a student's life. One student wrote of a faculty member she admired, "But she cares so much that students sometimes find it difficult to bring personal problems to her because she'll get too close to the problem and become far too involved." Faculty should beware of getting in over their heads; they should be familiar with campus counseling resources and know when to refer a student or even, on occasion, to walk a student to the counseling center personally. Faculty must respect students' individual development and never approach mentoring as a way to satisfy their own ego-needs.

Keeping boundaries clear is tricky sometimes. Students seem thrilled when invited to professors' homes, and many faculty find hosting students important to building productive relationships with them. But some faculty choose not to, as a deliberate measure to keep a professional distance - and good mentoring can happen either way. One professor, known as a supportive mentor, explains that, in order to avoid raising false expectations or abusing faculty power, "I have plenty of office hours but I don't have students to my home. I don't need them in my social life!” Another senior faculty member, wellknown as a generous and effective mentor, does invite students to his home; he believes students understand as well as he does that "mentoring and social life are completely different." Young faculty sometimes feel a particular need to maintain a degree of formality in their friendly relationships with students to keep the roles clear. But occasionally this confuses students who comment that "you notice when he shifts to a more professional, distant voice," or "I cannot decide what to make of her sometimes unusually formal 'on-guard' approach outside of class." In other cases, students occasionally misread friendly signals and believe that faculty want a more "intimate" relationship than they do. Of course, an actual intimate, sexual relationship between professor and student would be a severe violation of trust in the undergraduate setting, ${ }^{11}$ and it is the faculty member's responsibility to maintain that boundary. Mentoring is always "based on business"; it focuses on the student's business of learning and development.

Mentoring poses risks for the student, as well. A student who regards a professor as a mentor may place tremendous weight on whatever the faculty member says, and an off-hand remark may have undue influence, for good or ill, so faculty must be mindful in making comments. Occasionally, students perceive boundaries that faculty fail to observe. One student complained on his evaluation questionnaire that a professor mentioned in class something the student had shared in a private conversation. "I felt belittled," the student said, "and I lost a great deal of respect" for that faculty member. Mentors must preserve students' privacy and honor their trust.

A final danger is that mentoring might simply appear to be favoritism. A particularly promising student is "adopted" by a faculty member and gets special attention — and then we celebrate the 
beneficial outcomes. Is this fair to other students? Doesn't this undermine the essentially democratic ethos within an undergraduate college? Markie (1994) rightly asserts that "we are fundamentally obligated to give all students equal consideration in instruction, advising, and evaluation" but sees "friendship" with a few as out of bounds. He acknowledges that "professors who work with students beyond the classroom in ways that support learning are advancing the university's obligation to create a supportive educational environment" (p. 70), but his basic model of student behavior is a competitive one, and the thrust of his argument is against mentoring; he construes everything that I would call mentoring as "friendship" and therefore as favoritism, which he insists should be avoided at all costs ( $\mathrm{p}$. 68). But mentoring is not the same as friendship, so the question remains, is mentoring fair to other students not being mentored? The answer depends on institutional context. If mentoring is an unusual relationship on campus - if it is uncommon - then it may be viewed as favoritism (though it will still be beneficial to those involved). But if it occurs in a context that encourages broad student-faculty contact and student-centered learning in which mentoring blossoms with some frequency, then mentoring is not a result of favoritism but is a function of a campus culture that benefits many students.

\section{THE PAYOFF-IS IT WORTH IT?}

The research literature reports significant learning gains with outstanding mentoring (Lopatto, 2010), and testimony from my campus indicates that rewards of mentoring, both for students and faculty, extend further and can far outweigh potential risks. One alum eloquently summarized the benefits of mentoring by a faculty member who teaches a foreign language (not the student's major):

[ProfessorJ] is one of the most creative and exuberant professors ever. She helped me gain confidence in my ability and to love [her subject matter]. The first professor who ever invited me to her home, she took time to get to know each of us as people. [Subsequently,] there were many times that I sought her academic and personal advice outside the classroom. She always greeted me with a warm smile and many questions about my current activities. I admire [ProfessorJ] and value her as both a role model and a friend. Her influence ...was an integral part of my decision to pursue [an] international [career].

Many other alumni testify that a mentor "changed my life" in important and beneficial ways.

Faculty, too, benefit from mentoring, both personally and professionally. ${ }^{12}$ One wrote of supervising students in survey research, "this has been a wonderful working and learning experience for me. I help them understand the literature and frame the questions. They help me intuit the meanings of the answers we hear." Other faculty attest that getting to know some students really well through mentoring relationships helps make them better teachers in general, for, as one said, "[now] I understand where students' questions are coming from." For another, close interaction with advanced students is his "most intellectually rewarding" work; he relishes communication with alumni whom he has mentored: "When I look back on my work [here], I consider these [ongoing conversations with alumni] to be the most fulfilling and inspiring. They confirm, in a way that nothing else can, my love of what I do and where I do it." Another professor says simply, "Mentoring is its own reward." Such intrinsic satisfaction derives, in Erikson's terms (1964), from the fact that mentoring fulfills the major psychosocial need of adult life, "generativity," or making a difference for the next generation (pp. 130131).

Could all faculty be good mentors if they wanted to? According to one legendary mentor on my campus, mentoring is a natural talent and cannot be taught. I believe, however, that faculty can be 
coached as mentors, if they want to be. Clearly, not every faculty member will choose mentoring, or be good at it; some will excel at classroom teaching or research or administrative work instead. Even professors who might excel at mentoring may choose not to do so, given the opportunity cost in time not devoted to research or other activities.

But faculty members who decide to spend the time and energy required for mentoring must be supported and rewarded by their institutions. I don't suggest that mentoring should become a fourth category for faculty evaluation (with teaching, research, and service) that is required and assessed for salary or tenure and promotion decisions. Becoming another "box to check off" would undermine mentoring as a "natural" activity and reduce its effectiveness. But when it does happen, mentoring should be recognized and valued as a positive factor and be acknowledged in such decisions. Although distinguishable from teaching in important ways, for the purpose of faculty personnel decisions, I advocate considering mentorship as an extension to and enhancement of teaching, so it should "count" in that category, as in this example: senior colleagues praised a tenure candidate's extraordinary ability to recognize promise and "pull students up to a level which only he believed these students could ever reach!" Crediting this candidate's mentoring as crucial to his students' success contributed to a positive tenure decision. Such credit will encourage individual faculty who are inclined toward mentoring to decide that it is worth their while. Otherwise, if institutional rewards come only for publications or developing a new popular course (thus yielding the institution either research prestige or enrollment efficiency), faculty will be discouraged from doing the valuable work of mentoring and they and their undergraduates will miss out on important benefits. If encouraged and rewarded, however, faculty can find, through the personal connections of mentoring, rewards as great as the intellectual satisfaction they experience as effective classroom teachers. The most influential professors play both roles.

But why should mentoring be an institutional priority? In an era of strained resources, with Boards of Trustees lured by business models of efficiency and cost-cutting, and highly publicized rankings based on faculty research output or graduates' salaries, it is not easy for presidents and deans to raise one-on-one faculty-student interaction to a high priority. But if they focus on their institutions' educational mission and remember that "at its core, a college should be a place where young people find help navigating the territory between adolescence and adulthood" (Delbanco, 2012, p. 3), they ought to make mentoring a central commitment. Any college dedicated to educate the whole student, to prepare graduates not only for rewarding jobs but for leading fully realized lives (as the mission statement rhetoric of virtually any residential college asserts, in one form or another) should value and support faculty who mentor individual students. The payoff will be worth the cost: the result will be students who are more fully engaged in the life of the college (improving student learning and graduation rates), faculty who are more effective in the classroom because they know students better, and graduates who are more competent, self-assured, creative, and fulfilled in their subsequent lives and careers_-and probably more loyal and generous to their college.

Yes, the log with Mark Hopkins at one end and a student at the other has been replaced by sophisticated technology and posh campuses - but the essence of a good undergraduate education remains the same: personal, challenging, supportive interaction between a student and a faculty member. Mentoring makes the difference. ${ }^{13}$

Elizabeth McKinsey is Maxine H. and Winston R. Wallin Professor of American Studies and English at Carleton College. She has taught at Bryn Mawr College and Harvard University, was Director of the Bunting Institute at Harvard, and served as Dean of the College (chief academic officer) at Carleton for thirteen years. 


\section{NOTES}

1. The other six principles are "develops reciprocity and cooperation among students; uses active learning techniques; gives prompt feedback; emphasizes time on task; communicates high expectations; [and] respects diverse talents and ways of learning."

2. Other researchers have confirmed the importance of "frequent faculty contact, in and out of class" to student learning and development; see Hersh (2000), who summarizes research by Astin, Light, Boyer, Kuh and others.

3. The Wabash Study collects its own data, and also incorporates findings from the National Study of Student Engagement (NSSE).

4. A few of the essays in this volume are eloquent about the relationships a teacher can establish with students that may provide the basis for mentoring (such as those by Cohen (2001) and Coppola (2001)), but most don't take this crucial step. More recently, Dolan (2013) asserts that good teaching in theater is mentoring, and several other researchers focus on faculty as mentors, but only in formal research supervision roles, e.g. Monte (2001), Corley (2013), and Van Vliet, et al. (2013).

5. This quotation does identify the faculty member as a woman, which raises the question of gender and mentoring; my evidence does not suggest that gender affects the frequency or effectiveness of mentoring for either student or faculty. That is to say, both men and women are effective and committed mentors; both male and female students identified excellent mentors; and cross-gender mentoring and same-gender mentoring occurred with roughly equal frequency in my sample.

6. The 38 student quotations in this article are from 36 different students or young alumni.

7. Crisp and Cruz (2009) use the terms "formal or informal," "planned or spontaneous" (p. 529); I prefer "planned" and "natural" since I don't see unplanned mentoring as casual.

8. Both Crisp and Cruz (2009) and Gershenfeld (2014) decry the lack of rigorous controlled experimental research about mentoring; this is easier on planned mentoring than on natural, which may explain Gershenfeld's exclusive focus on research about planned mentoring programs.

9. Staff members can also be effective mentors at an undergraduate college, but my focus here is on faculty.

10. Kram (1983) and Zachary (2000) each posit four stages of a mentoring relationship, but both base their analysis on corporate settings. Kram identifies preparation, negotiating, enabling, and closure; Zachary sees initiation, cultivation, separation, and redefinition. These are not adequate to describe natural undergraduate mentorship.

11. Such a relationship is clearly prohibited by policy at my institution and, no doubt, at most traditionalage undergraduate institutions.

12. Anderson and Shore (2008) assert that there are few benefits to faculty for undergraduate mentoring as distinguished from graduate mentorship; my evidence contradicts this.

13. I want to thank the myriad students and alumni of Carleton College who have submitted evaluations for faculty reviews and the faculty who agreed to let me quote from their review prospectuses. Special thanks to the Carnegie Foundation for the Advancement of Teaching for their support as a Visiting Scholar to do the bulk of this research, and to colleagues who have discussed this research with me: John Ramsay, Pat Hutchings, Louis Newman, Frank Morral, David Schodt, Elizabeth Ciner, Roy Grow, Fred Hagstrom, Emily Clough, and Ken Sharpe. Finally, thanks to my best editor and intellectual colleague, my husband Tom Clough.

\section{REFERENCES}

Anderson, D.A., \& Shore, W.J. (2008). Ethical issues and concerns associated with mentoring undergraduate students. Ethics and Behavior, 18(1), 1-25.

Apprey, M., Preston-Grimes, P., Bassett, K.C., Lewis, D.W., \& Rideau, R.M. (2014). From crisis management to academic achievement: A university cluster-mentoring model for black undergraduates. Peabody Journal of Education, 89, 318-335.

Boyer, E.L. (1996). Foreword. In C. Kridel, R. V. Bullough, Jr., \& P. Shaker (Eds.) Teachers and mentors: Profiles of distinguished twentieth century professors of education. New York, NY: Garland.

Carger, C.L. (1996). The two Bills: Reflecting on the gift of mentorship. The Peabody Journal of Education, 71(1), 22-29. 
Chickering, A.W., \& Gamson, Z.F. (March 1987). Seven principles for good practice in undergraduate education. AAHE Bulletin, 3-7.

Chickering, A.W. \& Reisser, L. (1993). Education and identity ( $2^{\text {nd }}$ ed.). San Francisco, CA: Jossey-Bass.

Cohen, J. (Spring 2001). Mentoring undergraduates with professional and liberal arts goals: The mass communication experience. New Directions for Teaching and Learning, 85, 49-55.

Coppola, B.P. (Spring 2001). Full human presence: A guidepost to mentoring undergraduate science students. New Directions for Teaching and Learning, 8, 57-73.

Corley, C.R. (2013). From mentoring to collaborating: Fostering undergraduate research in history. The History Teacher, 46(3), 397-414.

Crisp, G., \& Cruz, I. (2009). Mentoring college students: A critical review of the literature between 1990 and 2007. Research in Higher Education, 50, 525-545.

Dallimore, E.J. (2001). The role of memorable messages in the socialization of new university faculty. Journal on Excellence in College Teaching, 12(2), 93-133.

Delbanco, A. (2012). College: What it was, is, and should be. Princeton, NJ: Princeton University Press.

Dodson, J.E., Montgomery, B.L., \& Brown, L.J. (2009). "Take the fifth": Mentoring students whose cultural communities were not historically structured into U.S. higher education. Innovations in Higher Education, 34, 185-199.

Dolan, J. (2013). To teach and to mentor: Toward our collective future. Theatre Topics, 23(1), 97-105.

Enerson, D. M. (Spring 2001). Mentoring as metaphor: An opportunity for innovation and renewal. New Directions for Teaching and Learning, 85, 7-13.

Erikson, E.H. (1950). Childhood and society. New York, NY: Norton.

Erikson, E.H. (1964). Insight and responsibility. New York, NY: Norton.

Erkut, S., \& Mokros, J.R. (Summer 1984). Professors as models and mentors for college students. American Educational Research Journal, 21(2). 399-417.

Garfield, J.A. (1871). Speech to Williams College alumni in New York. Retrieved April 27, 2014 from http://archives.williams.edu/williamshistory/greylock/mhopkins.php.

Gershenfeld, S. (2014). A review of undergraduate mentoring programs. Review of Educational Research, 84(3), 365-391.

Hersh, R.H. (2000). Generating ideals and transforming lives. In S. Koblik \& S.R. Graubard (Eds.), Distinctively American: The residential liberal arts colleges (pp. 172-194). Somerset, NJ: Transaction.

Horowitz, J., \& Christopher, K.B. (2013). The research mentoring program: Serving the needs of graduate and undergraduate researchers. Innovations in Higher Education, 38, 105-116.

Jacobi, M. (1991). Mentoring and undergraduate academic success: A literature review. Review of Educational Research, 64(1), 505-532.

Kanter, R.M. (1977). Men and women of the corporation. New York, NY: Basic Books.

Kartje, J.V. (1996). O mentor! My mentor! The Peabody Journal of Education, 71(1), 114-125.

Kram, K. E. (1983). Phases of the mentor relationship. The Academy of Management Journal, 26(4), 608-625.

Krockover, G.R. (1991). Reflections on professional mentorships. Teaching Education, 3(2), 113-114.

Leon, D. J. (1993). Mentoring minorities in higher education: Passing the torch. Washington, D.C.: National Education Association.

Levinson, D. J., Darrow, C. N., Klein, E. B., Levinson, M. H., \& McKee, B. (1978). The Seasons of a Man's Life. New York, NY: Knopf.

Lipschutz, S. S. (1993). Enhancing success in doctoral education: From policy to practice. New Directions for Institutional Research, 80, 69-80. doi: 10.1002/IR.37019938008

Lopatto, D. (2010). Undergraduate research as a high-impact student experience. Peer Review, 12(2). Retrieved August 24, 2015 from http://www.aacu.org/publications-research/periodicals/undergraduate-researchhigh-impact-student-experience

Markie, P. J. (1994). A professor's duties: Ethical issues in college teaching. New York, NY: Rowman \& Littlefield.

Monte, A. (December 2001). Mentor expectations and student responsibilities in undergraduate research. Council on Undergraduate Research Quarterly, 66-67.

Pascarella, E.T., Wolniak, G.C., Seifert, T.A.D., Cruce, T.M., \& Blaich, C.F. (2005). Liberal arts colleges and liberal arts education: New evidence on impacts. ASHE Higher Education Report, 31(3). San Francisco, CA: JosseyBass. 
Perry, W. G., Jr. (1970). Forms of intellectual and ethical development in the college years. New York, NY: Holt, Rinehart, \& Winston.

Rao, M. (1998). Developing new leaders: The role of relationships. Change. 30(1), 46-48.

Ray, J., \& Kafka, S. (2014). Life in college matters for life after college. Retrieved May 6, 2014 from http://www.gallup.com/poll/168848/life-college-matters-life-college.aspx.

Ream, R.K., Lewis, J.L., Echeverría, B., \& Page, R.N. (2014). Trust matters: Distinction and diversity in undergraduate science education. Teachers College Record, 116(5), 1-50.

Reinarz, A.G., \& White, E.R. (Eds.). (Spring 2001). Beyond teaching to mentoring. New Directions for Teaching and Learning, 85.

Schmidt, J.A., \& Wolfe, J.S. (1980). The mentor partnership: Discovery of professionalism. NAPSA Journal, 17(3), 4551.

Terrell, M.C. \& Hassell, R.K. (1994). Mentoring undergraduate minority students: An overview, survey, and model program. New Directions for Teaching and Learning, 57, 35-45.

Van Vliet, K.J., Klingle, K.E., \& Hiseler, L.E. (2013). The mentorship of undergraduate students in counseling psychology research. Counselling Psychology Quarterly, 26(3-4), 406-246.

Wabash National Study of Liberal Arts Education (2013). High-Impact Practices and Experiences from the Wabash National Study. Retrieved July 25, 2013 from http://static1.1.sqspcdn.com/static/f/333946/21582549/1357672916827/HighImpact_Practices_Summary_2013-01-11.pdf?token=3wd\%2BEk41TTnMfarkZmmvU9JUlcs\%3D

Wildman, T.M., Magliaro, S.G. \& Niles, R.A. (1992). Teacher mentoring: An analysis of roles, activities, and conditions. Journal of Teacher Education, 43(3), 205-213.

Wrightsman, L.S. (August 1981). Research methodologies for assessing mentoring. A paper presented at the American Psychological Association conference, Los Angeles, CA. (ERIC Document Reproduction Service No. ED 209-339).

Zachary, L.J. (2000). The mentor's guide: Facilitating effective learning relationships. San Francisco, CA: JosseyBass. and copyright for the publication layout resides with the journal. These copyright holders have agreed that this article should be available on open access under a Creative Commons Attribution License 4.0 International (https://creativecommons.org/licenses/by/4.0). The only constraint on reproduction and distribution, and the only role for copyright in this domain, should be to give authors control over the integrity of their work and the right to be properly acknowledged and cited, and to cite Teaching \& Learning Inquiry as the original place of publication. Readers are free to share these materials-as long as appropriate credit is given, a link to the license is provided, and any changes are indicated. 